The Canadian Mineralogist

Vol. 43, pp. 1131-1140 (2005)

\title{
$A{ }^{133} \mathrm{Cs},{ }^{29} \mathrm{Si}$, AND ${ }^{27} \mathrm{AI}$ MAS NMR SPECTROSCOPIC STUDY OF Cs ADSORPTION BY CLAY MINERALS: IMPLICATIONS FOR THE DISPOSAL OF NUCLEAR WASTES
}

\author{
REGINALD B. EJECKAM ${ }^{\S}$ \\ Atomic Energy of Canada Limited, Whiteshell Laboratories, Pinawa, Manitoba ROE 1LO, Canada \\ BARBARA L. SHERRIFF \\ Department of Geological Sciences, University of Manitoba, Winnipeg, Manitoba R3T 2N2, Canada
}

\begin{abstract}
A deep geological repository in stable plutonic rock is being considered for the long-term storage of spent nuclear fuel in Canada. In this study, we examine the adsorption of $\mathrm{Cs}^{+}$on clay minerals that may be used as engineered barriers in a repository or that are associated with fracture zones in the host rock. Ion-exchange experiments show that montmorillonite adsorbs more Cs than vermiculite, both 2:1 layer clay minerals. In the disordered structure of vermiculite, Cs was found to adsorb preferentially close to tetrahedral sites, where Al substitution for Si produced a local charge imbalance. Kaolinite, a 1:1 clay mineral, adsorbs very little cesium on its external surfaces. Elevated temperature and pressure, similar to those that would occur in an underground repository, do not affect the amount of $\mathrm{Cs}^{+}$adsorbed by montmorillonite. Cesium-133 MAS NMR spectroscopy indicates that $\mathrm{Cs}^{+}$is adsorbed in the interlayer of montmorillonite in two stages and in two environments: the layer of $\mathrm{H}_{2} \mathrm{O}$ molecules, where $\mathrm{Cs}^{+}$is surrounded by $\mathrm{H}_{2} \mathrm{O}$ molecules, and the layer closer to the clay surface, where $\mathrm{Cs}^{+}$is more tightly bonded to the basal oxygen atoms of the tetrahedra. The first stage of cesium adsorption is a rapid uptake in both the basal oxygen layer and the $\mathrm{H}_{2} \mathrm{O}$ molecule layer, in a ratio of 2:1. The $\mathrm{H}_{2} \mathrm{O}$ molecule layer reached its capacity immediately, and the amount of cesium adsorbed remains constant up to seven days. However, the adsorption in the basal oxygen layer increases after one hour to a ratio of 5:1 with respect to the $\mathrm{H}_{2} \mathrm{O}$ molecule layer, and remains at that level for the rest of the adsorption time.
\end{abstract}

Keywords: nuclear waste containment, montmorillonite, ${ }^{133} \mathrm{Cs},{ }^{29} \mathrm{Si},{ }^{27} \mathrm{Al}$ MAS NMR spectroscopy, cesium adsorption, ion exchange.

\section{SOMMAIRE}

On considère présentement un reposoir géologique profond dans une roche plutonique stable pour l'enfouissement à long terme de déchets nucléaires au Canada. Dans cette étude, nous examinons l'adsorption du $\mathrm{Cs}^{+}$sur des minéraux argileux qui pourraient être utilisés comme barrières planifiées autour du reposoir ou bien qui se trouvent le long de fractures dans la roche hôte. Les expériences sur l'échange ionique montrent que la montmorillonite adsorbe plus de Cs que la vermiculite, tous deux des argiles à couches 2:1. Dans la structure désordonnée de la vermiculite, le Cs devient adsorbé de préférence près de sites tétraédriques, où l'aluminium peut substituer au Si pour produire un écart local à l'électroneutralité. La kaolinite, un argile de type 1:1, adsorbe très peu de césium sur ses surfaces externes. Une température et une pression élevées, semblables aux conditions anticipées dans un reposoir souterrain, n'ont aucun effet sur le taux d'adsorption du $\mathrm{Cs}^{+}$sur la montmorillonite. La spectroscopie MAS NMR du césium-133 indique que le $\mathrm{Cs}^{+}$est adsorbé dans l'interfeuillet de la montmorillonite en deux stades et deux milieux: la couche de molécules d' $\mathrm{H}_{2} \mathrm{O}$, dans laquelle le $\mathrm{Cs}^{+}$est entouré de molécules de $\mathrm{H}_{2} \mathrm{O}$, et la couche plus près de la surface de l'argile, où le $\mathrm{Cs}^{+}$serait plus fortement lié aux atomes d'oxygène formant la base des tétraèdres. Le premier stade de l'adsorption du césium est rapide, et implique à la fois la couche d'atomes d'oxygène et la couche de molécules d' $\mathrm{H}_{2} \mathrm{O}$, dans une proportion de 2:1. La couche de molécules d' $\mathrm{H}_{2} \mathrm{O}$ atteint sa capacité immédiatement, et la quantité de césium adsorbée demeure constante pour jusqu'à sept jours. Toutefois, l'adsorption dans la couche d'atomes d'oxygène à la base des tétraèdres augmente après une heure dans un rapport de 5:1 par rapport au taux dans la couche de molécules de $\mathrm{H}_{2} \mathrm{O}$, et demeure inchangée pour le reste de la période d'adsorption.

(Traduit par la Rédaction)

Mots-clés: isolation de déchets nucléaires, montmorillonite, spectroscopie MAS NMR, isotopes ${ }^{133} \mathrm{Cs},{ }^{29} \mathrm{Si}$, ${ }^{27} \mathrm{Al}$, adsorption de césium, échange ionique.

$\S \quad$ Present address: Department of Geological Sciences, University of Manitoba, Winnipeg, Manitoba R3T 2N2, Canada. E-mail address: reg.ejeckam@shaw.ca 


\section{INTRODUCTION}

CANada Deuterium Uranium (CANDU) nuclear reactors have generated approximately $15 \%$ of all electricity produced in Canada over the last fifty years, and almost half of the electricity in Ontario currently is being produced by nuclear energy. A number of radioactive elements, including $\mathrm{Cs}$, are produced, either by nuclear fission inside the uranium oxide fuel pellets, or by neutron activation of metals and impurities in the fuel assembly. Most radioactive isotopes of Cs have short half-lives, so that within 10 years, Cs represents less than $1 \%$ of the radioactive waste products (Johnson et al. 1994). However, ${ }^{135} \mathrm{Cs}$ produced by the fission of ${ }^{235} \mathrm{U}$ has a half-life of 2.3 million years. This is a problem for long-term waste disposal, as Cs is soluble and hence mobile in water (Comans et al. 1991, Maiti et al. 1989).

At present, spent fuel is stored at sites of nuclear power generation in water-filled pools for at least ten years, before being transferred to reinforced concrete dry-storage containers at the reactor sites, where it can be monitored (AECL 1994). Disposal in a deep geological repository is being considered for longterm storage of high-level nuclear waste in Canada. Spent nuclear fuel, sealed in durable metal containers, would be placed in a network of tunnels and emplacement rooms 500 to $1000 \mathrm{~m}$ deep in stable plutonic rock of the Canadian Shield (AECL 1994, Simmons \& Baumgartner 1994, Davison et al. 1994a, b). Backfill comprised of glacial clay and bentonite surrounding the metal container would buffer and slow the movement of groundwater. Bentonite is a sedimentary rock that contains montmorillonite, and has hydrophilic and swelling properties. Clays minerals in permeable fracture zones in the host plutonic rock that resulted from alteration of the wall rock could adsorb radionuclides, thereby retarding their migration to the surface and hence into the food chain. These clay minerals include kaolinite, vermiculite and montmorillonite (McMurry \& Ejeckam 2002).

In this study, the processes controlling the adsorption of $\mathrm{Cs}$ onto individual clay minerals were investigated by means of ion-exchange experiments. Changes in the chemical environment of the sorption sites were observed with magic angle spinning - nuclear magnetic resonance spectroscopy (MAS NMR). Ion-exchange was also done at elevated temperatures and pressure to simulate conditions similar to those present at depth in the repository. Radionuclides may also adsorb on biofilms, which are slimy polymers produced by bacteria. Biofilms with negative surface charges can become sorption sites for positively charged ions (Brown \& Sherriff 1999) such as $\mathrm{Cs}^{+}$. In the presence of iron oxides, biofilms may grow rapidly, clogging open pore-spaces and preventing the free movement of groundwater while acting as a sorptive "sponge" or storage site for radionuclides (Stroes-Gascoyne \& West 1997).

\section{REVIEW OF RELEVANT WORK}

Phyllosilicates have been studied by solid-state NMR (Weiss et al. 1990a, b, Kim et al. 1996a, b, Kim \& Kirkpatrick 1998, Sullivan et al. 1998), and sorption isotherms have been found for $\mathrm{Cs}^{+}, \mathrm{Sr}^{2+}$ and $\mathrm{Ba}^{2+}$ (an analog for $\mathrm{Ra}^{2+}$ ) onto kaolinite and smectite clays (Westrich et al. 1998) at $25^{\circ}, 50^{\circ}$ and $70^{\circ} \mathrm{C}$ over $\mathrm{pH}$ values from 2 to 12 . Kim et al. (1996b) and Weiss et al. (1990a) showed that $\mathrm{Cs}^{+}$adsorption in expandable clay minerals occurs at two sites, with $\mathrm{Cs}^{+}$being relatively tightly bound to the basal oxygen atoms or loosely bonded to $\mathrm{H}_{2} \mathrm{O}$ molecules. In other NMR studies, Kim et al. (1996b) concluded that $\mathrm{Cs}^{+}$is adsorbed on the basal surfaces and on broken edges of kaolinite clay. Weiss et al. (1990b) used variable temperatures to study the motion of Cs adsorbed on clay mineral, and found that there was a motional averaging of Cs between the sites when the samples were saturated to $100 \%$ relative humidity (RH). However, after complete dehydration, there was no motional averaging. In addition, a general trend of deshielding of $\mathrm{Cs}^{+}$occurred with increased $\mathrm{Al}^{3+}$ substitution for $\mathrm{Si}^{4+}$ (Weiss et al. 1990b), as there are fewer electrons to shield the ${ }^{133} \mathrm{Cs}$ nucleus, giving a more strongly positive position of the peak.

\section{Materials And Methods}

\section{Materials}

Montmorillonite (STx-1), kaolinite (KGa-1) and vermiculite $(\mathrm{VTx}-1)$ were obtained from the Source Clay Repository of the Clay Mineral Society (CMS), Missouri, USA. X-ray-diffraction (XRD) results indicate that the bulk sample labeled vermiculite (VTx-1) is not pure and contains a number of other minerals. In order to avoid contamination from the other minerals, grain aggregates of vermiculite were separated from the bulk sample by handpicking, after which the vermiculite aggregates were ground with a mortar and pestle. The XRD pattern of the handpicked grains is consistent with pure vermiculite (Brindley 1980). The kaolinite sample (KGa-1) gave an XRD pattern that is consistent with pure kaolinite (Brindley 1980). Montmorillonite sample $\mathrm{STx}-1$ was found to contain a trace amount of a silica phase, identified by Liang \& Sherriff (1993) as cristobalite, which is intergrown and could not be separated.

\section{Ion-exchange experiments}

In the initial ion-exchange experiments, $6 \mathrm{~g}$ montmorillonite, kaolinite, and vermiculite were each weighed into $500 \mathrm{~mL}$ beakers, to which $50 \mathrm{~mL}$ of 0.1 
$\mathrm{M}$ aqueous $\mathrm{CsCl}$ solution was added. These were left on a mechanical rocker for six hours, and then the residues were washed and oven-dried at $80^{\circ} \mathrm{C}$ for 6 hours.

For exchange experiments at higher temperature and pressure, $6 \mathrm{~g}$ montmorillonite $(\mathrm{STx}-1)$ were weighed into three $500 \mathrm{~mL}$ glass beakers and $50 \mathrm{~mL}$ of $0.1 \mathrm{M}$ aqueous $\mathrm{CsCl}$ solution added and mixed to form a slurry. For the $80^{\circ} \mathrm{C}$ adsorption experiment, $200 \mathrm{~mL}$ of solution were used to compensate for evaporation from the open beakers in the oven. After 6 hours, the beakers were removed from the oven, allowed to cool for 30 minutes, and the clear liquid decanted. The clay residues were washed three times with $50 \mathrm{~mL}$ of distilled water and oven-dried at $80^{\circ} \mathrm{C}$ for 6 hours. In the higher pressure and higher temperature experiment, $150 \mathrm{~mL}$ of $0.1 \mathrm{M}$ aqueous $\mathrm{CsCl}$ solution was mixed with $6 \mathrm{~g}$ montmorillonite and heated in a pressure cooker. The temperature and pressure were recorded each hour for 6 hours before the pressure cooker was allowed to cool for one hour, and the samples washed and dried in the oven. To investigate the adsorption of cesium in the presence of an active bacteria consortium, ion-exchange experiments were conducted by addition of an active bacteria culture in the cesium ion-exchange experiment with montmorillonite using the same weight of cesium plus clay and experimental conditions.

To measure the rate of adsorption of Cs, $1.2 \mathrm{~g}$ of montmorillonite (STx-1) were weighed into glass vials and $10 \mathrm{~mL}$ of $0.1 \mathrm{M} \mathrm{CsCl}$ was added. The first set of triplicate samples (M1-1, M2-1 and M3-1) were shaken to mix and were then filtered immediately (within one minute) using a Buchner filter system with $10-\mu \mathrm{m}$ filter paper. The vials and filters were washed with $10 \mathrm{~mL}$ of distilled water. The clay residues were air-dried for 20 minutes before being oven-dried at $80^{\circ} \mathrm{C}$ for 6 hours. The second set of the triplicate samples (M1-2, M2-2 and M3-2) were washed after 10 minute of adsorption time, then dried as above. Subsequent triplicate sets were washed after additional 10-minute intervals for the first hour, then after each hour for the next six hours, and then each day for the next seven days.

The oven-drying process is believed to have no effect on the clay mineral structure or the adsorption process. Clay minerals, montmorillonite in particular, have two sources of $\mathrm{H}_{2} \mathrm{O}$; adsorbed water and hydroxyl $\mathrm{H}_{2} \mathrm{O}$. Adsorbed water is lost at about $110^{\circ} \mathrm{C}$ during heating, and its release is also dependent on the hydration energy. Hydroxyl $\mathrm{H}_{2} \mathrm{O}$ is lost from the clay structure when two hydroxyl groups combine to form a $\mathrm{H}_{2} \mathrm{O}$ molecule. This occurs at even higher temperature. Dehydroxylation of smectite occurs between 500 and $700^{\circ} \mathrm{C}$ (Borchardt 1977), although Grim (1968) observed that $\mathrm{Ca}$-dominant montmorillonite showed a gradual loss of cation-exchange capacity on heating to $300^{\circ} \mathrm{C}$, and loses its lattice $\mathrm{H}_{2} \mathrm{O}$ at $700^{\circ} \mathrm{C}$. These temperatures are much higher than the drying temperatures used in our experiment. Therefore, the $80^{\circ} \mathrm{C}$ drying temperature should not affect the clay-mineral structure or its cation-exchange capacity.

\section{Analytical techniques}

Inductively coupled plasma (ICP) - optical emission spectrometry (OES) and atomic absorption (AA) were used to analyze the clay minerals before and after ion exchange. The clays were dried at $110^{\circ} \mathrm{C}$ overnight, before $0.1 \mathrm{~g}$ samples were weighed into $50 \mathrm{~mL}$ centrifuge tubes with $8.5 \mathrm{~mL} \mathrm{HNO}_{3}$ and $1.5 \mathrm{~mL} \mathrm{HF}$ to digest the sample. After mixing, the samples were heated in a CEM model MDS 2100 microwave oven for one hour. Twenty $\mathrm{mL}$ of distilled water was added to the cooled acid solution before being heated in the microwave oven for another hour. This solution was then diluted 500 -fold with distilled water. Aliquots of each sample were analyzed for Cs using a Varian AA spectrometer, model 300 and for major elements with a Varian Liberty 200 ICP-OES. Structural formulae were calculated with the program FORMULA.

\section{Nuclear magnetic resonance spectroscopy}

The MAS NMR spectra were collected using a Bruker AMX500 spectrometer with a 11.7 Tesla magnet. Powdered samples, packed in zirconia rotors, were spun at 5 to $8 \mathrm{kHz}$ in a Doty Scientific MAS probe. The ${ }^{27} \mathrm{Al}$ spectra were obtained at a frequency of 130.3 $\mathrm{MHz}$, with a $15^{\circ}$ pulse angle, a relaxation delay of 0.5 $\mathrm{s}$, and from 900 to 6000 scans. The ${ }^{29} \mathrm{Si}$ spectra were obtained at a frequency of $99.3 \mathrm{MHz}$, a pulse width of $4 \mu \mathrm{s}$, relaxation delays of $5 \mathrm{~s}$, and from 150 to 7000 scans. Peak positions for ${ }^{27} \mathrm{Al}$ were measured relative to $1.0 \mathrm{M}$ aqueous solution of aluminum chloride $\left(\mathrm{AlCl}_{3}\right)$ and for ${ }^{29} \mathrm{Si}$ to tetramethylsilane (TMS). For ${ }^{133} \mathrm{Cs}$, spectra were obtained at a frequency of $65.6 \mathrm{MHz}$, and a pulse width of $1 \mu \mathrm{s}$, with a relaxation delay of $1 \mathrm{~s}$, and between 700 and 8000 scans. Relative intensities of ${ }^{133} \mathrm{Cs}$ peaks were obtained by physically cutting out and weighing the peaks areas and associated sidebands using hard copies of the spectra. This technique gave more consistent results for the broad overlapping ${ }^{133} \mathrm{Cs}$ peaks than computer simulations of the spectra. These values were converted to weight percent Cs using the results of the chemical analyses.

\section{RESUlTS AND DisCUSSION}

Kaolinite, of ideal formula $\mathrm{Al}_{2}\left[\mathrm{Si}_{2} \mathrm{O}_{5}\right](\mathrm{OH})_{4}$, is a 1:1 type of clay mineral with a low cation-exchange capacity (CEC) owing to the lack of exchangeable interlayer cations. Montmorillonite, of ideal formula $(\mathrm{Ca}, \mathrm{Na})_{\mathrm{x}}(\mathrm{Al}, \mathrm{Mg}, \mathrm{Fe})_{2}\left[(\mathrm{Si}, \mathrm{Al})_{4} \mathrm{O}_{10}\right](\mathrm{OH})_{2} \bullet n \mathrm{H}_{2} \mathrm{O}$, and vermiculite, of ideal formula $(\mathrm{Mg}, \mathrm{Ca})_{x}(\mathrm{Mg}, \mathrm{Al}, \mathrm{Fe})_{3}$ $\left[(\mathrm{Si}, \mathrm{Al})_{4} \mathrm{O}_{10}\right](\mathrm{OH})_{2} \bullet n\left(\mathrm{H}_{2} \mathrm{O}\right)$ are $2: 1$ clay minerals. In each group of the 2:1 layer minerals, the clays can be 
dioctahedral, with two trivalent cations in the octahedral layer, or trioctahedral, with three divalent cations. Tetrahedrally coordinated $\mathrm{Al}^{3+}$ may partially replace $\mathrm{Si}^{4+}$, creating an excess negative charge that can be neutralized by adsorption of cations such as $\mathrm{Ca}^{2+}, \mathrm{Na}^{+}$, and $\mathrm{Mg}^{2+}$. The adsorbed cations for montmorillonite may provide insufficient positive charge to completely neutralize the negative charge, leaving it susceptible to partial or a complete ion-exchange (Faure 1998). Vermiculite has a higher negative charge in the layer of tetrahedra owing to a higher concentration of $\mathrm{Al}^{3+} ; \mathrm{Mg}^{2+}$ is the dominant exchangeable cation in the interlayer (Deer et al. 1998).

These differences in cation-exchange capacity were reflected in the adsorption of Cs shown by the clays (Table 1). Montmorillonite adsorbed about $6 \% \mathrm{Cs}$, and increases in temperature and pressure had no significant effect. This result allows the sorption experiments at room temperature and pressure to be used for the prediction of the processes occurring under the temperature and pressure conditions expected in an underground repository. A microbial community, which would be present in the repository, slightly enhanced the adsorption of Cs to a total of $7.5 \mathrm{wt} \%$ owing to the formation of a polysaccharide biofilm (Ejeckam \& Sherriff 2003, Stroes-Gascoyne et al. 2000).

In the ion-exchange experiment designed to measure the rate of adsorption, the amount of Cs adsorbed by montmorillonite in the first minute was about $4 \mathrm{wt} \%$, and it remained at this level for the first hour. At the end of one hour, the amount of cesium adsorbed increased to about $6 \mathrm{wt} \%$ and remained at this level for the remaining seven days of the experiment (Fig. 1).

Vermiculite (VTx-1), with only 0.04 atoms per formula unit (apfu) of $\mathrm{Ca}^{2+}$, compensated for 0.33 apfu $\mathrm{Cs}^{+}$adsorbed with losses of $\mathrm{Na}^{+}(0.11 \mathrm{apfu})$ and $\mathrm{Mg}^{2+}$ (1.1 apfu). Insufficient $\mathrm{Cs}^{+}$was adsorbed on vermiculite to compensate for the $\mathrm{Mg}^{2+}$ lost (Table 2, columns 1A and B). Kaolinite adsorbed very little $\mathrm{Cs}^{+}(0.04 \mathrm{apfu})$, with little accompanying change in composition (Table 2, columns $2 \mathrm{~A}$ and $\mathrm{B}$ ). In contrast, montmorillonite, which adsorbed the highest amount of Cs (0.39 apfu), showed reductions in $\mathrm{Ca}^{2+}$ from 0.23 to 0.02 apfu, $\mathrm{Mg}^{2+}$ from 0.54 to $0.45 a p f u$, and $\mathrm{Na}^{+}$from 0.11 to $0.03 \mathrm{apfu}$. Montmorillonite lost $91 \%$ and $75 \%$ of its initial $\mathrm{Ca}^{2+}$

TABLE 1. AMOUNT OF CS ADSORBED BY CLAY MINERALS

\begin{tabular}{lll}
\hline \multicolumn{1}{c}{ Mineral } & \multicolumn{1}{c}{ Conditions } & Cesium (wt\%) \\
\hline Montmorillonite (STx-1) & RT, P & $6.1 \pm 0.2$ \\
Montmorillonite (STx-1) & $80^{\circ} \mathrm{C}$ & $6.6 \pm 0.03$ \\
Montmorillonite (STx-1) & $107^{\circ} \mathrm{C}, 1.5$ bars & $6.2 \pm 0.2$ \\
Montmorillonite (STx-1) + active bacteria** & RT, P & $7.5 \pm 0.4$ \\
Vermiculite (VTx-1) & RT, P & $3.8 \pm 0.0$ \\
Kaolinite (KGa-1) & RT, P & $0.8 \pm 0.0$ \\
& & \\
\end{tabular}

* Ejeckam \& Sherriff (2003). and $\mathrm{Na}^{+}$concentration respectively, which are replaced by $\mathrm{Cs}^{+}$(Table 2, columns $3 \mathrm{~A}$ and $\mathrm{B}$ ).

The ${ }^{27} \mathrm{Al}$ and ${ }^{29} \mathrm{Si}$ spectra of montmorillonite, vermiculite and kaolinite can be related to their chemical compositions. The ${ }^{27} \mathrm{Al}$ spectrum of montmorillonite consists of a single peak due to octahedral $\mathrm{Al}$ at $2.3 \mathrm{ppm}$. The expected peak due to the small amount of Al calculated to be in the tetrahedral site could be hidden by the broad spinning sidebands at about 60 ppm (Table 3, Fig. 2). The single ${ }^{29} \mathrm{Si}$ peak at -93.5 ppm (Table 4, Fig. 3) shows that there was insufficient $\mathrm{Al}$ in the tetrahedral site to produce disorder (Table 2). A broad peak at $-111 \mathrm{ppm}$ is attributed to the presence of cristobalite (Liang \& Sherriff 1993) or amorphous silica. Both the ${ }^{27} \mathrm{Al}$ and ${ }^{29} \mathrm{Si}$ peaks shifted to lower frequency with Cs adsorption, indicating increased shielding. The change in ${ }^{29} \mathrm{Si}$ peak position increased from $0.2 \mathrm{ppm}$ to $0.5 \mathrm{ppm}$ with adsorption at $80^{\circ} \mathrm{C}$, and to $0.6 \mathrm{ppm}$ for the higher pressure and temperature adsorption (Table 4, Fig. 3).

The ${ }^{27}$ Al MAS NMR spectrum of vermiculite consists of a large peak at $66.4 \mathrm{ppm}$ due to $\mathrm{Al}$ in tetrahedral configuration, and a small peak at $8.8 \mathrm{ppm}$ due to $\mathrm{Al}$ in octahedral coordination (Table 3, Fig. 4). This spectrum does not agree with the calculated formula for vermiculite, in which all $\mathrm{Al}$ is in tetrahedral coordination (Table 2). The ${ }^{\mathrm{VI}} \mathrm{Al}$ peak shows a decrease of $0.6 \mathrm{ppm}$ in

\begin{tabular}{|c|c|c|c|c|c|c|}
\hline & $1 \mathrm{~A}$ & $1 \mathrm{~B}$ & $2 \mathrm{~A}$ & $2 \mathrm{~B}$ & $3 \mathrm{~A}$ & $3 \mathrm{~B}$ \\
\hline $\mathrm{SiO}_{2} \mathrm{wt} \%$ & 35.59 & 40.29 & 34.28 & 35.87 & 51.38 & 50.71 \\
\hline $\mathrm{Al}_{2} \mathrm{O}_{3}$ & 5.80 & 5.37 & 42.61 & 43.45 & 15.75 & 15.03 \\
\hline $\mathrm{TiO}_{2}$ & 0.89 & 0.91 & n.d. & n.d. & n.d. & n.d. \\
\hline $\mathrm{Fe}_{2} \mathrm{O}_{3}$ & 5.77 & 5.58 & 0.04 & 0.05 & 0.53 & 0.41 \\
\hline $\mathrm{MnO}$ & 0.04 & 0.03 & 0.00 & 0.00 & n.d. & n.d. \\
\hline $\mathrm{MgO}$ & 21.01 & 17.09 & 0.02 & 0.0 & 2.46 & 1.99 \\
\hline $\mathrm{CaO}$ & 0.22 & 0.42 & 0.02 & 0.01 & 1.49 & 0.11 \\
\hline $\mathrm{Na}_{2} \mathrm{O}$ & 0.36 & 0.01 & 0.09 & 0.07 & 0.37 & 0.11 \\
\hline $\mathrm{K}_{2} \mathrm{O}$ & 5.43 & 5.22 & 0.04 & 0.03 & 0.10 & 0.08 \\
\hline $\mathrm{CsO}_{2}$ & 0.00 & 4.87 & 0.00 & 0.81 & 0.00 & 6.10 \\
\hline Total & 76.11 & 80.51 & 81.05 & 80.28 & 72.09 & 74.53 \\
\hline Si apfu & 5.79 & 6.37 & 3.81 & 3.86 & 7.52 & 7.64 \\
\hline${ }^{\mathrm{IV}} \mathrm{Al}$ & 1.11 & 1.00 & 0.19 & 0.14 & 0.48 & 0.37 \\
\hline${ }^{\mathrm{V}} \mathrm{Al}$ & - & & 5.39 & 5.36 & 2.24 & 2.30 \\
\hline $\mathrm{Ti}$ & 0.11 & 0.11 & 0.00 & 0.00 & n.d. & n.d. \\
\hline $\mathrm{Fe}^{3+}$ & 0.78 & 0.74 & 0.00 & 0.00 & 0.05 & 0.05 \\
\hline $\mathrm{Mg}$ & 5.09 & 4.03 & 0.00 & 0.00 & 0.54 & 0.45 \\
\hline $\mathrm{Mn}^{2+}$ & 0.01 & 0.00 & 0.00 & 0.00 & n.d. & n.d. \\
\hline Cs & 0.00 & 0.33 & 0.00 & 0.04 & 0.00 & 0.39 \\
\hline $\mathrm{Ca}$ & 0.04 & 0.07 & 0.00 & 0.00 & 0.23 & 0.02 \\
\hline $\mathrm{Na}$ & 0.11 & 0.00 & 0.02 & 0.02 & 0.11 & 0.03 \\
\hline $\mathrm{K}^{+}$ & 1.13 & 1.05 & 0.01 & 0.00 & 0.02 & 0.02 \\
\hline $\mathrm{H}^{+}$ & 4.00 & 4.00 & 4.00 & 4.00 & 4.00 & 4.00 \\
\hline CATSUM & 14.17 & 13.71 & 9.42 & 9.42 & 11.18 & 11.25 \\
\hline $\mathrm{O}$ & 22.00 & 22.00 & 18.00 & 18.00 & 22.00 & 22.00 \\
\hline
\end{tabular}

Note: 1 vermiculite, 2 kaolinite, 3 montmorillonite. 
peak position with $\mathrm{Cs}$ adsorption, indicating an increase in the nuclear shielding by electrons, whereas the ${ }^{\mathrm{IV}} \mathrm{Al}$ peak remains constant within the error of the measurement. Vermiculite has three ${ }^{29} \mathrm{Si}$ MAS NMR peaks, at $-84.4,-88.4$ and $-92.8 \mathrm{ppm}$, which shift to $-85.6,-88.7$ and $-92.8 \mathrm{ppm}$ after Cs adsorption (Table 4, Fig. 5). The three peaks, assigned to $\mathrm{Q}^{3}(2 \mathrm{Al}), \mathrm{Q}^{3}(1 \mathrm{Al})$ and $\mathrm{Q}^{3}(0 \mathrm{Al})$ respectively (the superscript refers to the number of adjacent tetrahedrally coordinated atoms), have been previously interpreted to be due to disorder caused by $16 \%$ of the tetrahedral sites containing $\mathrm{Al}$ (Thompson 1984). There was a decrease in the extent of peak shift due to increased shielding, with Cs adsorption from 1.2 $\mathrm{ppm}$ for the $\mathrm{Si}(2 \mathrm{Al} 1 \mathrm{Si})$ site to $0.3 \mathrm{ppm}$ for the $\mathrm{Si}(1 \mathrm{Al}$ $2 \mathrm{Si})$ site. The peaks due to the $\mathrm{Si}(3 \mathrm{Si})$ do not shift with

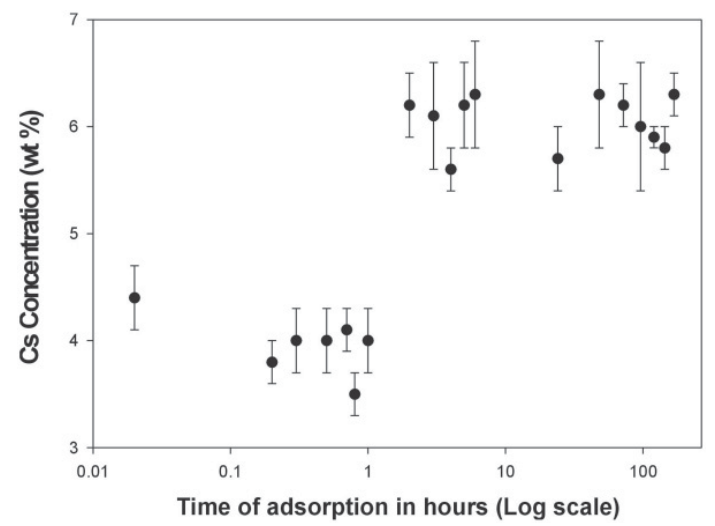

FIG. 1. Rate of Cs adsorption by montmorillonite.

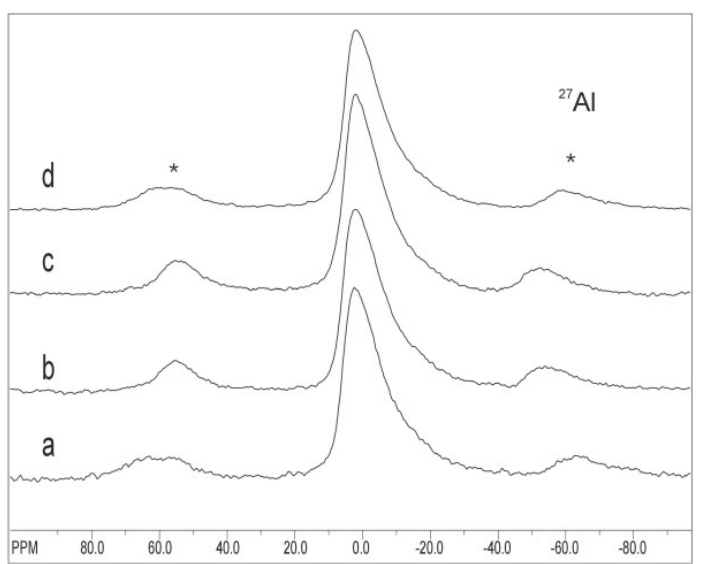

FIG. 2. ${ }^{27} \mathrm{Al}$ spectra of montmorillonite, (a) before Cs adsorption, and after Cs adsorption at (b) ambient conditions, (c) $80^{\circ} \mathrm{C}$, and (d) $107^{\circ} \mathrm{C}, 1.5$ bar. * Indicates spinning sidebands.
Cs adsorption. This difference in shift indicates that $\mathrm{Cs}^{+}$ is preferentially adsorbed to the oxygen atoms of the $\mathrm{SiO}_{4}$ sites adjacent to $\mathrm{Al}$, which have the highest local charge-imbalance.

The single peaks due to octahedral ${ }^{27} \mathrm{Al}$ and tetrahedral ${ }^{29} \mathrm{Si}$ of kaolinite agree with the calculated formula that there is less than $5 \% \mathrm{Al}$ in the tetrahedral sites. Both ${ }^{27} \mathrm{Al}$ and ${ }^{29} \mathrm{Si} \mathrm{NMR}$ peaks exhibit the opposite effect on $\mathrm{Cs}^{+}$adsorption to montmorillonite and vermiculite, with both ${ }^{27} \mathrm{Al}$ and ${ }^{29} \mathrm{Si}$ peaks becoming slightly less shielded (Table 3,4). As only 0.04 apfu Cs was adsorbed by kaolinite (Table 2), this deshielding may be due to expansion of the clay as a result of the adsorption of $\mathrm{H}_{2} \mathrm{O}$ molecules during the experiments.

Cesium-133 has a natural abundance of $100 \%$, a spin number (I) of $7 / 2$, but a very small electric quadrupole moment (Q). Chemical shifts range from +100 to -500

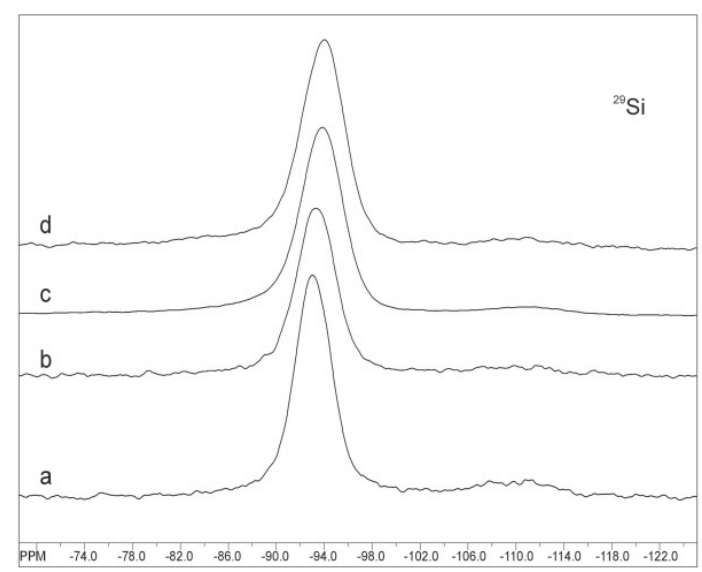

FIG. 3. ${ }^{29} \mathrm{Si}$ spectra of montmorillonite (a) before Cs adsorption, and after Cs adsorption at (b) ambient conditions, (c) $80^{\circ} \mathrm{C}$, and (d) $107^{\circ} \mathrm{C}, 1.5$ bar.

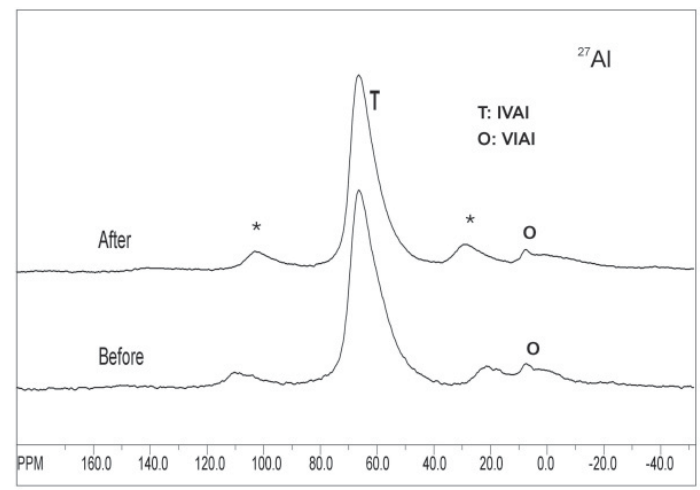

FIG. 4. ${ }^{27} \mathrm{Al}$ spectra of vermiculite before and after $\mathrm{Cs}$ adsorption. * Indicates spinning sidebands. 
ppm relative to a $0.1 \mathrm{M}$ aqueous solution of $\mathrm{CsCl}$, although Hartman et al. (1998) found values outside this range owing to unpaired electrons. The peak positions of ${ }^{133} \mathrm{Cs}$ adsorbed in clays are dependent on the absolute humidity or water content of the air in the NMR laboratory (Kim et al. 1996b). Variation in humidity is a major problem in Winnipeg, with completely different spectra being obtained in the $-30^{\circ} \mathrm{C}$ winter with extremely low absolute humidity, even in the laboratory at $25^{\circ} \mathrm{C}$, compared to $+30^{\circ} \mathrm{C}$ summer temperatures with higher absolute humidity (Fig. 6). At $-30^{\circ} \mathrm{C}, 1 \mathrm{~kg}$ of air can only hold $0.3 \mathrm{~g}$ of water vapor, whereas at $+30^{\circ} \mathrm{C}$ it can hold $26.5 \mathrm{~g}$ (Tarbuck \& Lutgens 2000). The ${ }^{133} \mathrm{Cs}$ MAS NMR spectrum of montmorillonite obtained in March, when winter conditions still prevailed, gave a noisy and unresolved spectrum. However, when the same sample was run in July, it gave a much better resolved spectrum, with two distinguishable peaks (Fig. 6). The ${ }^{133} \mathrm{Cs}$ spectra used here were obtained in the summer, but the peak positions should not be treated as absolute values, as there is rarely high absolute humidity in Winnipeg.

The initial ${ }^{133} \mathrm{Cs}$ MAS NMR spectrum of kaolinite consists of three small peaks at $213 \mathrm{ppm},-21.4 \mathrm{ppm}$ and $-50.7 \mathrm{ppm}$, which all disappear after the sample is washed for a second time, indicating a weak surficial adsorption. The peak at $213 \mathrm{ppm}$ is due to solid $\mathrm{CsCl}$.

The ${ }^{133} \mathrm{Cs}$ spectrum of vermiculite has one broad peak at $42.5 \mathrm{ppm}$, with large spinning sidebands. This is similar to the peak found by Weiss et al. (1990a) at $55.1 \mathrm{ppm}$, which they assigned to dehydrated Cs in the interlayer sites, tightly bound to the basal oxygen atoms because of the large negative charge on the layer of tetrahedra.

The ${ }^{133} \mathrm{Cs}$ MAS NMR spectrum of montmorillonite after ion exchange at room temperature and pressure has two peaks (Fig. 7), the largest at $-28.4 \mathrm{ppm}$ (Peak 1), with a peak width of about $800 \mathrm{~Hz}$, and a smaller

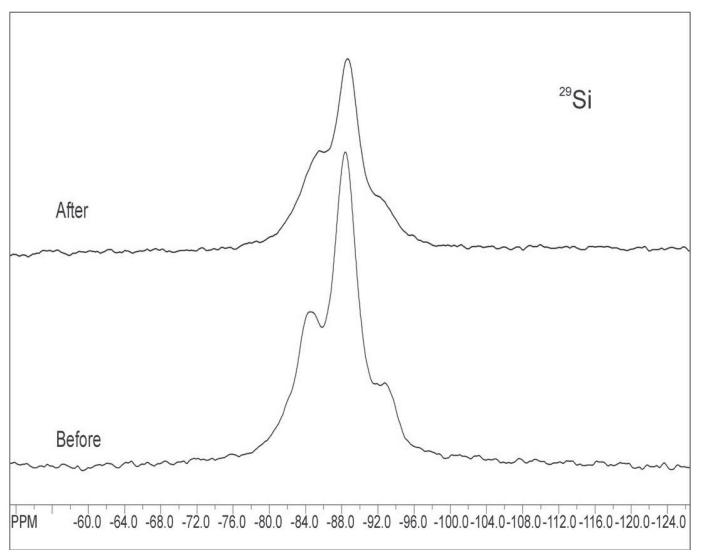

FIG. 5. ${ }^{29} \mathrm{Si}$ spectra of vermiculite before and after Cs adsorption. one at $23.5 \mathrm{ppm}$ (Peak 2), with a peak width of about $1300 \mathrm{~Hz}$. The frequency of Peak 1 was $-26.5 \mathrm{ppm}$ for the sample exchanged at $80^{\circ} \mathrm{C}$ and $-24.5 \mathrm{ppm}$ after higher temperature and pressure exchange. Peak 2 was at a constant frequency. The amount of Cs represented by each peak was calculated from the relative intensity of the peaks and the chemical composition (Fig. 8). The amount of Cs represented by Peak 2 remains constant at about $1 \mathrm{wt} \%$, whereas the amount shown by Peak 1 increased after 1 hour of adsorption time from 2.5 to $5.5 \mathrm{wt} \%$ (Fig. 8).

Sullivan et al. (1998) and Weiss et al. (1990a, b) proposed that when montmorillonite is hydrated, cations adsorbed in the interlayer are separated from the clay surfaces by $\mathrm{H}_{2} \mathrm{O}$ molecules and able to move freely throughout the interlayer. They may exchange rapidly between a surface-bonded and hydrated species. Kim et al. (1996b) reported that $\mathrm{Cs}^{+}$adsorption in illite occurs at two locations, CS1 and CS2, which are equivalent to the basal oxygen layer and the layer of $\mathrm{H}_{2} \mathrm{O}$ molecules, respectively. The chemical shift of $\mathrm{Cs}$ in the CS1, but not CS2, changed with composition of the clay

\begin{tabular}{lrcc}
\multicolumn{2}{c}{ TABLE 3. ${ }^{27} \mathrm{Al}$ MAS NMR PEAK POSITIONS BEFORE AND AFTER } \\
ION EXCHANGE
\end{tabular}

$\pm 0.1 \mathrm{ppm}$.

TABLE $4 .{ }^{29}$ Si MAS NMR CHEMICAL SHIFTS BEFORE AND AFTER ION EXCHANGE

\begin{tabular}{|c|c|c|c|c|}
\hline \multirow{2}{*}{ Mineral } & \multicolumn{3}{|c|}{${ }^{29}$ Si chemical shift (ppm) } & \multirow[b]{2}{*}{ Assignment } \\
\hline & Before & After & Change & \\
\hline Montmorillonite (STx-1) & -93.5 & -93.7 & -0.2 & $\mathrm{Q}^{3}(0 \mathrm{Al})$ \\
\hline \multicolumn{3}{|l|}{ Montmorillonite (STx-1) } & -0.5 & $\mathrm{Q}^{3}(0 \mathrm{Al})$ \\
\hline \multicolumn{5}{|l|}{ Montmorillonite (STx-1) } \\
\hline $107^{\circ} \mathrm{C}, 1.5$ bars & -93.5 & -94.1 & -0.6 & $\mathrm{Q}^{3}(0 \mathrm{Al})$ \\
\hline Kaolinite (KGa-1) & -91.4 & -91.1 & +0.3 & $\mathrm{Q}^{3}(0 \mathrm{Al})$ \\
\hline \multirow[t]{3}{*}{ Vermiculite (VTx-1) } & -84.4 & -85.6 & -1.2 & $\mathrm{Q}^{3}(2 \mathrm{Al})$ \\
\hline & -88.4 & -88.7 & -0.3 & $\mathrm{Q}^{3}(1 \mathrm{Al})$ \\
\hline & -92.8 & -92.8 & 0.0 & $\mathrm{Q}^{3}(0 \mathrm{Al})$ \\
\hline
\end{tabular}

$\pm 0.1 \mathrm{ppm}$. 


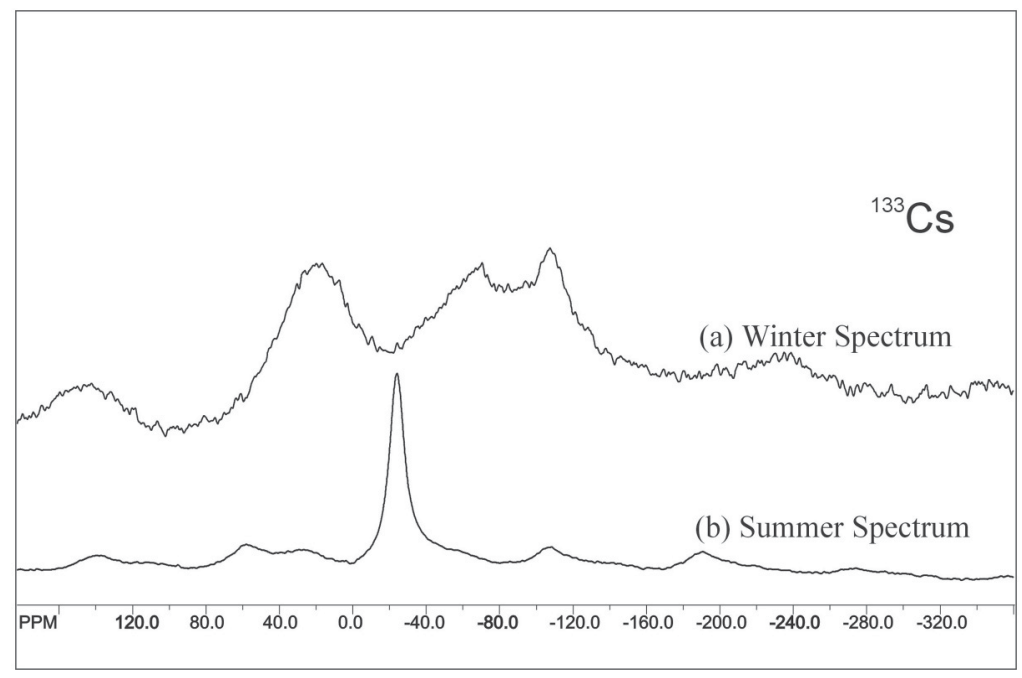

FIG. 6. ${ }^{133} \mathrm{Cs}$ spectra of the same montmorillonite sample obtained in (a) winter and (b) summer.

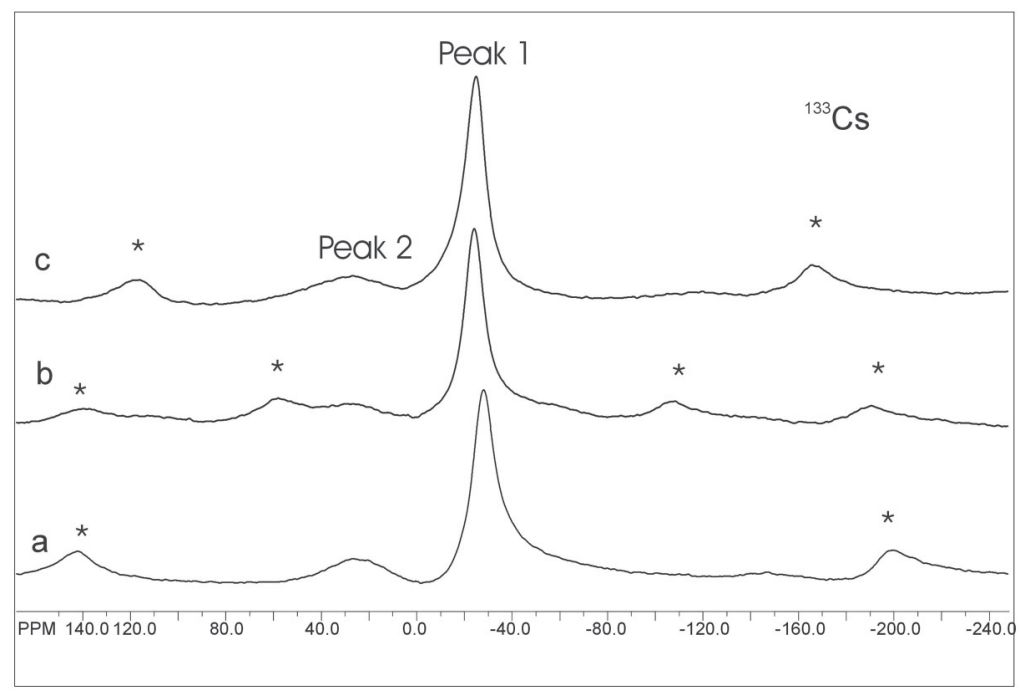

FIG. 7. ${ }^{133} \mathrm{Cs}$ MAS NMR spectrum of montmorillonite after Cs absorption at (a) RTP, (b) $80^{\circ} \mathrm{C}$, and (c) $107^{\circ} \mathrm{C}$ and 1.5 bars. * Indicates spinning sidebands.

minerals, becoming more shielded with increasing Si: Al ratio (Kim et al. 1996b). The CS1 peaks were more negative and narrower than those from the CS2 sites, showing $\mathrm{Cs}^{+}$to be more tightly bonded (Kim et al. 1996b). In this study, Peak 1 is the more shielded of the two peaks, and so was assigned to sites bonded to the basal oxygen atoms of the layer of tetrahedra. As Peak 2 is less shielded, it was assigned to the diffuse
$\mathrm{Cs}^{+}$atoms surrounded by $\mathrm{H}_{2} \mathrm{O}$ molecules. During initial adsorption on montmorillonite, $\mathrm{Cs}^{+}$enters the basal oxygen bonded and hydrated sites in a ratio of about $2: 1$. After about one hour, this ratio increases to $5: 1$, which represents the final stable configuration (Fig. 8). This multisite adsorption model, also proposed by Comans et al. (1991), could explain the variable rate of adsorption of Cs in montmorillonite. 


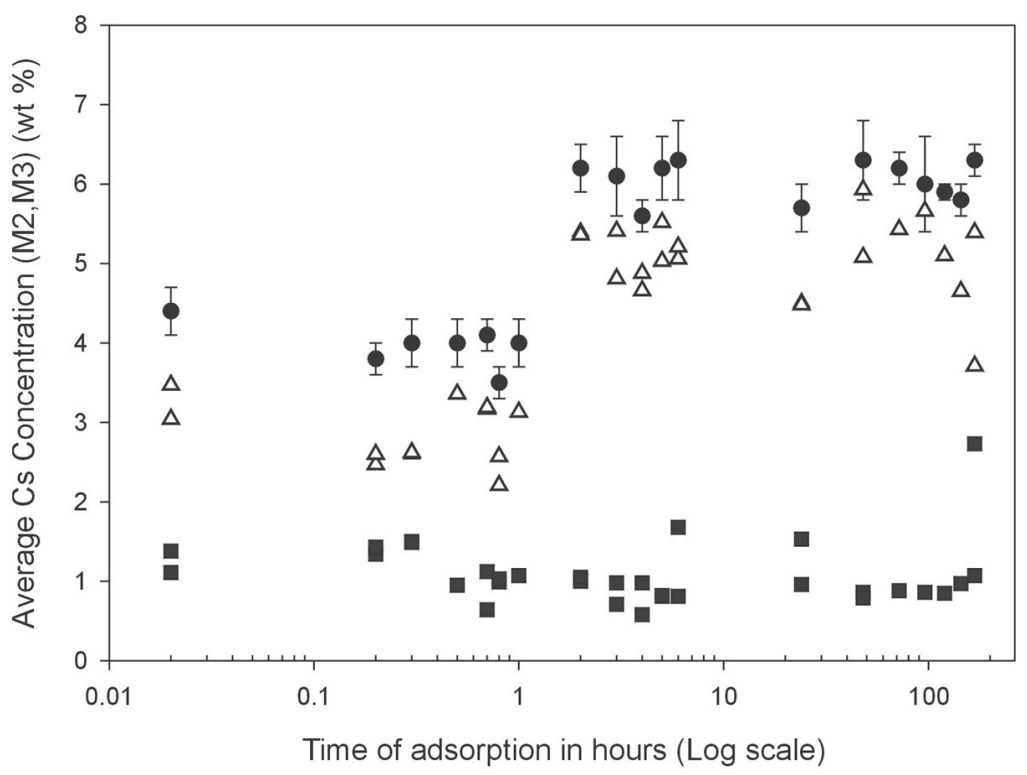

FIG. 8. Amount of Cs adsorbed at two sites in the interlayer of montmorillonite, as calculated from the ${ }^{133} \mathrm{Cs}$ MAS NMR, Peak 1 at the layer of basal oxygen atoms (open triangles) and Peak 2 at the layer of $\mathrm{H}_{2} \mathrm{O}$ molecule (solid squares). Solid circles with error bars show total amounts.

\section{Implications for nuclear waste}

This study is important to the long-term storage of radioactive waste in a deep geological repository because clay minerals are an important component of materials in the design of the repository. Clay minerals are also products of alteration, either from hydrothermal alteration or from the long-term interaction of groundwater with the granitic host-rock. The waste in a metal container will be placed in storage room cut in the granite, and backfilled with bentonite and crushed granite. Should the metal container be breached, the radionuclides could escape from the vault, and be transported by the groundwater through the permeable fractures to the surface. In this study, montmorillonite clay present in the engineered barrier and the fractures has been shown to be able to adsorb and remove radioactive cesium from solution. This study shows that the majority of $\mathrm{Cs}^{+}$adsorbed by montmorillonite (a major component of bentonite) becomes strongly bonded rapidly to the basal oxygen atoms of the silicate tetrahedra. This finding is important because it indicates that $\mathrm{Cs}^{+}$will be strongly held. Further research would be necessary to measure the rate of desorption of cesium.

\section{CONCLUSIONS}

Cesium is adsorbed at several sites of the clay minerals, on the surface of kaolinite and in the interlayer of 2:1 clay minerals, with kaolinite adsorbing less $\mathrm{Cs}^{+}$than vermiculite and montmorillonite. Adsorption is rapid on all clay minerals, and takes less than one minute. The adsorption of $\mathrm{Cs}^{+}$on montmorillonite occurs in two stages. The first stage involves the rapid uptake of $\mathrm{Cs}$ by attachment to the oxygen atoms of the $\mathrm{H}_{2} \mathrm{O}$ molecules in the interlayer, and the second stage involves the slower process that continues as $\mathrm{Cs}^{+}$ attaches to the basal atoms of oxygen of the aluminosilicate tetrahedra. Elevated temperature and pressure do not affect the amount of Cs adsorbed.

Cesium adsorption caused the environment of adjacent $\mathrm{Si}$ and $\mathrm{Al}$ atoms to become more shielded, causing negative shifts in ${ }^{27} \mathrm{Al}$ and ${ }^{29} \mathrm{Si}$ MAS NMR spectra of adjacent nuclei. Only Si sites with adjacent Al atoms were affected for vermiculite.

\section{ACKNOWLEDGEMENTS}

We are grateful to Terry Wolowiec and Dr. Kirk Marat, Department of Chemistry, University of Mani- 
toba, for their assistance with NMR instrumentation, and to Gregg Morden, Department of Geological Sciences, University of Manitoba, for his help in the analysis of the clay minerals. This research was funded by the Natural Sciences and Engineering Research Council of Canada through a Discovery Grant to BLS and by Atomic Energy of Canada Limited. We thank Drs. R. Kotzer, J. Percival, D. Paktunc, R.F. Martin, and an anonymous reviewer for helpful comments on this manuscript.

\section{REFERENCES}

AECL (1994): Environmental Impact Statement (EIS) on the concept for disposal of Canada's nuclear fuel waste. Atomic Energy of Canada Limited Rep. AECL-10721*, $496 \mathrm{p}$.

BORCHARDT, G.A. (1977): Montmorillonite and other smectite minerals. In Minerals in Soil Environments ( $2^{\text {nd }}$ edition; J.B. Dixon \& S.B. Weed, eds.). Soil Science Society of America, Madison, Wisconsin (293-330).

BRINDLEY, G.W. (1980): Order-disorder in clay mineral structure. In Crystal Structures of Clay Minerals and their X-ray Identification (G.W. Brindley \& G. Brown, eds.). Mineral Soc., Monogr. 5, 125-195.

Brown, D.A. \& SherRIFF, B.L. (1999): Evaluation of the effect of microbial subsurface ecosystems on spent nuclear fuel repositories. Environmental Technology 20, 469-477.

Comans, R.N.J., Haller, M. \& De Preter, P. (1991): Sorption of cesium on illite: non-equilibrium behaviour and reversibility. Geochim. Cosmochim. Acta 55, 433-440.

Davison, C.C., Brown, A., Everitt, R.E., Gascoyne, M., Kozak, E.T., Lodha, G.S., Martin, C.D., SoOnawala, N.M., Stevenson, D.R. Thorne, G.A. \& Whitaker, S.H. (1994a): The disposal of Canada's nuclear fuel waste: site screen and site evaluation technology. Atomic Energy of Canada Limited Rep. AECL-10713, COG-93-3*, $255 \mathrm{p}$.

Chan, T., Brown, A., Gascoyne, M., Kamineni, D.C., Lodha, G.S., Melnyk, T.W., NakKa, B.W., O'Connor, P.A., Ophori, D.U., SCHEIER, N.W., SOONawala, N.M., Stanchell, F.W., Stevenson, D.R., THORNE, G.A., VANDERGRAAF, T.T., VilKs, P. \& WhitAKER, S.H. (1994b): The disposal of Canada's nuclear fuel waste: the geosphere model of postclosure assessment. Atomic Energy of Canada Limited Rep. AECL-10719, COG-93-9*, 497 p.

DeER, W.A., HowIE, R.A. \& Zussman, J. (1998): An Introduction to the Rock-Forming Minerals ( $2^{\text {nd }}$ ed.). Longman Scientific and Technical Press, Hong Kong (279-387).

EJECKAM, R.B. \& SHERRIFF, B.L. (2003): Adsorption of Cs on the fracture filling clay minerals of the Lac du Bonnet batholith, SE Manitoba: implications for nuclear fuel waste disposal. Proc. Two Rivers Conf., 56 $6^{\text {th }}$ Canadian Geotechnical Conf., $4^{\text {th }}$ Joint IAH-CNC/CGS Conf. (Winnipeg).
FAURE, G. (1998): Principles and Applications of Geochemistry ( $2^{\text {nd }}$ ed.). Prentice Hall, Englewood Cliffs, New Jersey.

GRIM, R.E. (1968): Clay Mineralogy ( $2^{\text {nd }}$ ed.). McGraw-Hill, New York, N.Y. (185-233).

Hartman, J.S., Vance, E.R., Power, W.P. \& Hanna, J.V. (1998): A ${ }^{133} \mathrm{Cs}$ magic angle spinning nuclear magnetic resonance study of cesium environments in barium hollandites and SYNROC. J. Mater. Res. 13, 22-27.

Johnson, L.H., Tait, J.C., Shoesmith, D.W., Crosthwaite, J.L. \& Gray, M.N. (1994): The disposal of Canada's nuclear fuel waste: engineered barriers alternatives. Atomic Energy of Canada Limited Rep. AECL-10718, COG-93-8, $418 \mathrm{p}$.

Kim, Y., CYgan, R.T. \& KirkPATRICK, R.J. (1996a): ${ }^{133} \mathrm{Cs}$ NMR and XPS investigation of cesium adsorbed on clay minerals and related phases. Geochim. Cosmochim. Acto 60, 1041-1052.

\& KIRKPATRICK, R.J. (1998): NMR T1 relaxation study of ${ }^{133} \mathrm{Cs},{ }^{23} \mathrm{Na}$ adsorbed on illite. Am. Mineral. 83, 661-665.

\& CYGAN, R.T. (1996b): ${ }^{133}$ Cs NMR study of cesium on the surface of kaolinite and illite. Geochim. Cosmochim. Acta 60, 4059-4074.

LIANG, J. \& SHERRIFF, B.L. (1993): Lead exchange into zeolite and clay minerals: ${ }^{29} \mathrm{Si},{ }^{27} \mathrm{Al},{ }^{23} \mathrm{Na}$ solid state NMR study. Geochim. Cosmochim. Acta 57, 3885-3894.

Maiti, T.C., SMith, M.R. \& LAUL, J.C. (1989): Colloid formation study of uranium, thorium, radium, lead, polonium, strontium, rubidium, and cesium in briny (high ionic strength) groundwater: analog study for waste disposal. Nucl. Technol. 84, 82-87.

MCMurRY, J. \& EJeCKAM, R.B. (2002): Paleohydrogeological study of fracture mineralogy in the Whiteshell research area. Ontario Power Generation Nuclear Waste Management Division, Rep. 06819-REP-01200-10082-R00.

Simmons, G.R. \& Baumgartner, P. (1994): The disposal of Canada's nuclear fuel waste: engineering for a disposal facility. Atomic Energy of Canada Limited Rep. AECL10715*, COG-93-5, $331 \mathrm{p}$.

Stroes-Gascoyne, S., Haveman, S.A., Hamon, C.J. \& TicKNOR, K.V. (2000): Analysis of biofilms grown in situ at AECL's underground research laboratory on granite, titanium and copper coupons. Atomic Energy of Canada Limited Rep. AECL-12098*, 82 p.

\& West, J.M. (1997): Microbial studies in the Canadian nuclear fuel waste management program. FEMS Microbial Rev. 20, 573-590.

Sullivan, D.J., Shore, J.S. \& RiCE, J.A. (1998): Assessment of cation-binding to clay-minerals using solid-state NMR. Clays Clay Minerals 46, 349-354. 
TARBUCK, E.J. \& LUTGENS, F.K. (2000): Earth Science $\left(^{\text {th }}\right.$ ed.). Prentice Hall, Englewood Cliffs, New Jersey (407418).

ThOmpson, J.G. (1984): ${ }^{29} \mathrm{Si}$ and ${ }^{27} \mathrm{Al}$ nuclear magnetic resonance spectroscopy of 2:1 clay minerals. Clay Minerals 19, 229-236.

Weiss, C.A., JR., KiRKPATRICK, R.J. \& Altaner, S.P. (1990a): The structural environments of cations adsorbed onto clays: ${ }^{133} \mathrm{Cs}$ variable-temperature MAS NMR spectroscopic study of hectorite. Geochim. Cosmochim. Acta 54, 1655-1669.

\& (1990b): Variations in interlayer cation sites of clay minerals as studied by ${ }^{133} \mathrm{Cs}$
MAS nuclear magnetic resonance spectroscopy. Am. Mineral. 75, 970-982.

Westrich, H.R., Brady, P.V., Cygan, R.T., Gruenhagen, S.E., ANDERSON, H.L. \& NAGY, K.L. (1998): Characterization of Retardation Mechanism in Soil. NUREG/CR-6603 SAND98-0419, $23 \mathrm{p}$.

* Unrestricted, unpublished report, available from Scientific Document Distribution Office (SDD0), Atomic Energy of Canada Ltd. Company, Chalk River, Ontario K1J 1J0, Canada.

Received December 20, 2003, revised manuscript June 15, 2004. 